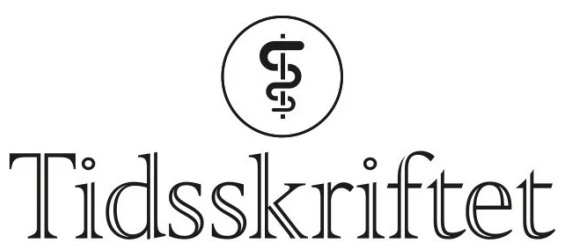

DEN NORSKE LEGEFORENING

\title{
Kreftbehandling med isolert ekstremitetsperfusjon
}

KLINISK OVERSIKT

\section{MILAN SPASOJEVIC}

milspa@ous-hf.no

Seksjon for onkologisk bekkenkirurgi

Avdeling for gastrokirurgi

Oslo universitetssykehus, Radiumhospitalet

Han har bidratt med idé, utforming/design, litteratursøk, utarbeiding og godkjenning av innsendte manusversjon.

Milan Spasojevic er dr.med., spesialist i generell kirurgi og i gastroenterologisk kirurgi og overlege. Forfatteren har fylt ut ICMJE-skjemaet og oppgir ingen interessekonflikter.

\section{ANTHONY B. MARIATHASAN}

Seksjon for onkologisk bekkenkirurgi

Avdeling for gastrokirurgi

Oslo universitetssykehus, Radiumhospitalet

Han har bidratt med idé, utforming, utarbeiding/revisjon av manuset og godkjenning av innsendte manusversjon.

Anthony B. Mariathasan er spesialist i generell kirurgi og i gastroenterologisk kirurgi og overlege. Forfatteren har fylt ut ICMJE-skjemaet og oppgir ingen interessekonflikter.

\section{LARS FRICH}

Seksjon for onkologisk plastikkirurgi

Plastikkirurgisk avdeling

Oslo universitetssykehus, Radiumhospitalet

Han har bidratt med utforming/design, litteratursøk, utarbeiding/revisjon av manuset og godkjenning av innsendte manusversjon.

Lars Frich er dr.med., spesialist i generell kirurgi og i plastikkirurgi, overlege og medisinsk redaktør i Tidsskriftet.

Forfatteren har fylt ut ICMJE-skjemaet og oppgir ingen interessekonflikter.

\section{ØYVIND S. BRULAND}

Seksjon for sarkomer Onkologisk avdeling Oslo universitetssykehus, Radiumhospitalet og

Institutt for klinisk medisin

Universitetet i Oslo

Han har bidratt med utforming/design, utarbeiding/revisjon av manuset og godkjenning av innsendte manusversjon.

Øyvind S. Bruland er dr.med., spesialist i onkologi og professor.

Forfatteren har fylt ut ICMJE-skjemaet og oppgir ingen interessekonflikter. 
Seksjon for onkologisk bekkenkirurgi

Avdeling for gastrokirurgi

Oslo universitetssykehus, Radiumhospitalet

Han har bidratt med utforming/design, utarbeiding/revisjon av manuset og godkjenning av

innsendte manusversjon.

Stein G. Larsen er dr.med., spesialist i generell kirurgi og i gastroenterologisk kirurgi og

seksjonsoverlege.

Forfatteren har fylt ut ICMJE-skjemaet og oppgir ingen interessekonflikter.

\section{STEPHAN STOLDT}

Seksjon for onkologisk bekkenkirurgi

Avdeling for gastrokirurgi

Oslo universitetssykehus, Radiumhospitalet

Han har bidratt med idé, utforming/design, utarbeiding/revisjon av manuset og godkjenning av innsendte manusversjon.

Stephan Stoldt er spesialist i generell kirurgi og i gastroenterologisk kirurgi og overlege.

Forfatteren har fylt ut ICMJE-skjemaet og oppgir ingen interessekonflikter.

\section{For lokalavanserte bløtvevssarkomer og metastaser fra melanom lokalisert til ekstremitet kan mutilerende kirurgi eller amputasjon være nødvendig for å oppnå lokal kontroll. Isolert ekstremitetsperfusjon med cellegift i høy dose kan være et alternativ til amputasjon for denne pasientgruppen.}

Ved isolert ekstremitetsperfusjon (isolated limb perfusion, ILP) isoleres blodforsyningen til en ekstremitet fra den systemiske sirkulasjonen og ekstrakorporal sirkulasjon etableres ved en perfusjonsmaskin. Slik kan cytotoksiske medikamenter administreres til ekstremiteten med opptil 20-25 ganger høyere konsentrasjon enn hva som er mulig ved intravenøs behandling med minimal systemisk påvirkning (1).

Isolert ekstremitetsperfusjon er hovedsakelig brukt ved multiple metastaser fra melanom lokalisert til en ekstremitet og som preoperativ behandling ved ikke-resektable eller marginalt resektable bløtvevssarkomer. Indikasjoner er vist i ramme 1 (2). Isolert ekstremitetsperfusjon forutsetter god perifer sirkulasjon i ekstremiteten som skal behandles. Okklusjon av hovedarterie til ekstremiteten eller diabetes med alvorlig mikroangiopati anses som absolutte kontraindikasjoner. Infiserte sår, tidligere omfattende kirurgi på ekstremiteten, uttalt hevelse eller betydelig redusert perifer sirkulasjon er relative kontraindikasjoner (3).

\section{Ramme 1 Indikasjoner for behandling med isolert ekstremitetsperfusjon}

(2)

Neoadjuvant behandling ved primære lokalavanserte bløtvevssarkomer i ekstremitet der amputasjon eller mutilerende kirurgi er den eneste muligheten for å oppnå frie reseksjonsmarginer

Lokalt residiv av bløtvevssarkomer i ekstremitet

Behandlingsresistente metastaser fra melanom i ekstremitet

Artikkelen gir en oversikt over historisk utvikling av isolert ekstremitetsperfusjon, og vi diskuterer indikasjon, behandlingsprinsipper og resultater. Artikkelen er basert på ikkesystematiske litteratursøk i PubMed og egen klinisk erfaring.

\section{Historikk}


Bruk av perfusjonsmaskin til administrasjon av cellegift ved ekstrakorporal sirkulasjon til ekstremitet ble først beskrevet i 1958 (1). Dette var også første gang melfalanbasert perfusjon ble brukt for behandling av melanom. En studie publisert i 1992 beskrev for første gang bruk av tumornekrosefaktor-alfa (TNF- $\alpha$ ) i kombinasjon med interferon-gamma (IFN- $\gamma$ ) og melfalan for lokalavanserte bløtvevssarkomer (4).) Isolert ekstremitetsperfusjon for lokalavanserte bløtvevssarkomer ble etablert ved flere sentre i Europa etter at en multisenterstudie med 186 pasienter i 1996 viste en betydelig behandlingsrespons hos $82 \%$ av pasientene (5).

\section{Operativ prosedyre}

Isolert ekstremitetsperfusjon utføres i generell anestesi. Arterie og vene til den aktuelle ekstremiteten fridissekeres. Katetre legges inn i karene og kobles til en perfusjonsmaskin. Et turniké strammes rundt ekstremiteten proksimalt for innstikksstedet i karene for å isolere ekstremiteten fra den systemiske sirkulasjonen. Ekstrakorporal sirkulasjon av ekstremiteten etableres ved hjelp av en perfusjonsmaskin som sirkulerer, varmer opp og oksygenerer blodet (figur 1). Temperaturen i vevet registreres.

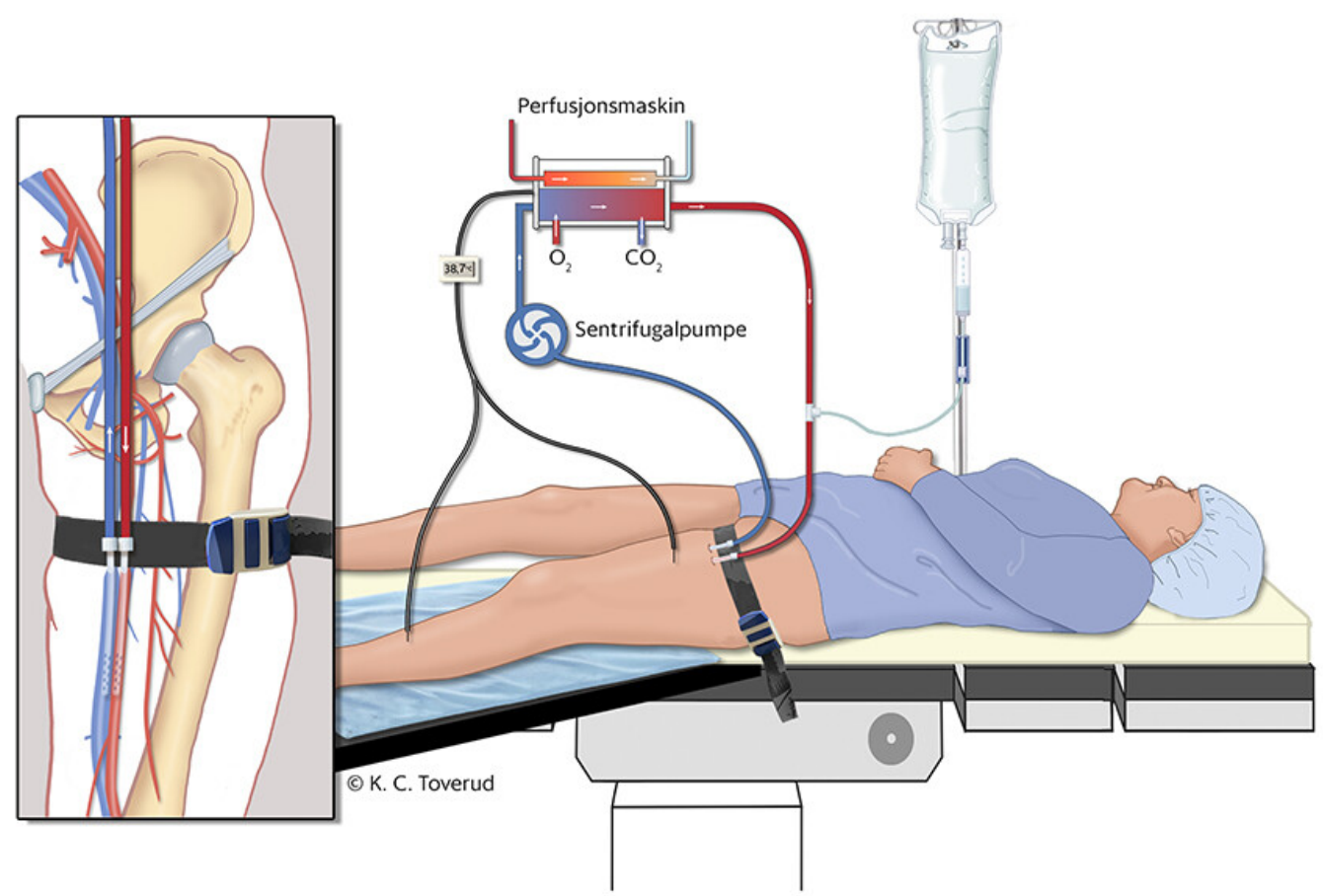

Figur 1 Skjematisk illustrasjon av isolert ekstremitetsperfusjon. Det er lagt kateter i arterie og vene til ekstremiteten som skal behandles. Et turniké er lagt rundt ekstremiteten proksimalt, slik at ekstremiteten isoleres fra den systemiske sirkulasjonen. Ekstrakorporal sirkulasjon etableres med en perfusjonsmaskin som sirkulerer, varmer opp og oksygenerer blodet til ekstremiteten. Kjemoterapi administreres til ekstremiteten gjennom det ekstrakorporale kretsløpet.

Radioaktivt sporingsstoff/tracer ( ${ }^{99}{ }^{\mathrm{m}}$ Tc-merket albumin) administreres via perfusjonsmaskinen til ekstremiteten. En gammadetektor plasseres over hjertet for å måle eventuell lekkasje av sporingsstoff fra ekstremiteten til den systemiske sirkulasjonen. Dersom lekkasjen er mindre enn $<10 \%$ og temperaturen i ekstremiteten er innenfor terapeutisk mål $\left(38-40^{\circ} \mathrm{C}\right)$, startes perfusjon av ekstremiteten med melfalan, eventuelt i kombinasjon med TNF- $\alpha$. Behandlingsvarighet er 6o-9o minutter. Avslutningsvis fjernes katetrene i arterie og vene, og sirkulasjonen til ekstremiteten reetableres.

\section{Melfalan og TNF- $\alpha$}


Melfalan er hjørnesteinen i isolert ekstremitetsperfusjon på grunn av kraftig cytotoksisk effekt gjennom alkylering av DNA og skadelig effekt på RNA, proteiner og lipider (므). I motsetning til mange andre alkylerende medikamenter trenger melfalan ikke å omdannes til aktiv form i kroppen. Det gjør den spesielt egnet til isolert ekstremitetsperfusjon. Melfalan stimulerer antitumorimmunitet og kan bidra til induksjon av tumorregresjon i flere uker etter avsluttet behandling (.7.).

Brukt sammen med melfalan har TNF- $\alpha$ synergistisk effekt ved at det $ø$ ker melfalanopptaket i tumor opptil 4-6 ganger ( $\underline{8})$. Denne effekten oppnås sannsynlig gjennom direkte og selektiv destruksjon av endotelet i tumorkar, som videre fører til økt karpermeabilitet og redusert interstitielt trykk. TNF- $\alpha$ i kombinasjon med melfalan er i dag mest brukt til behandling av bløtvevssarkomer. Kombinasjonen benyttes sjeldnere ved melanom, ettersom den ved behandling av melanomer øker toksisiteten uten å gi onkologisk gevinst (9-11).

\section{Hypertermi}

Hypertermi $ø$ ker den cytotoksiske effekten av alkylerende midler (므). Best balanse mellom den cytotoksiske effekten og lokal toksisitet oppnås ved mild hypertermi $\left(38-40^{\circ} \mathrm{C}\right)$. Ved behandling av eldre pasienter og pasienter med vesentlig komorbiditet kan normoterm isolert ekstremitetsperfusjon $\left(37-38^{\circ} \mathrm{C}\right)$ vurderes (11).

\section{Toksisitet}

Regional toksisitet rapporteres ved hjelp av Wieberdinks klassifikasjon (13). Dette er en skala i fem trinn, der grad I er ingen reaksjon, grad II noe rødme/hevelse, grad III uttalt rødme/hevelse, grad IV uttalt epidermolyse og/eller skade på dype strukturer og grad V nekrose som kan kreve amputasjon. Grad II- og III-toksisitet rapporteres hos over $90 \%$ av pasientene. Grad IV-toksisitet, som også inkluderer kompartmentsyndrom, rapporteres hos $1-5 \%$ av pasientene (14). Grad V-toksisitet beskriver stor vevsskade som nødvendiggjør amputasjon av ekstremitet, og forekommer i 1-3\% av tilfellene (15).

Systemisk toksisitet kan forekomme ved medikamentlekkasje til den systemiske sirkulasjonen. Lekkasje fra ekstremiteten til den systemiske sirkulasjonen skyldes oftest rikelig kollateralsirkulasjon i ekstremiteten, som er vanskelig å okkludere fullstendig. Ved mer enn 10 \% lekkasje av melfalan anbefales det å avbryte prosedyren (15). De vanligste bivirkningene ved systemisk melfalanlekkasje er beinmargsdepresjon, hårtap, utslett, kløe, kvalme og stomatitt. TNF- $\alpha$ kan forårsake hypotensjon allerede ved $1 \%$ systemisk lekkasje, mens lekkasjer som er større enn 10 \%, kan føre til et alvorlig sepsislignende syndrom (15).

\section{Responsrate og overlevelse}

Ved metastaser fra melanom er komplett og partiell respons etter isolert ekstremitetsperfusjon henholdsvis $25 \%$ og $39 \%$ etter tre måneder (므). Hos pasienter med komplett respons er lokal residivrate $41 \%$, med median tid til utvikling av residiv på 11 måneder. I en systematisk oversiktsartikkel ble det rapportert en median femårsoverlevelse på $37 \%$ (19-50 \%) blant 931 pasienter (9.). For pasienter med bløtvevssarkomer er komplett og partiell respons etter tre måneder henholdsvis $22-31 \%$ og 46-54\%, med mulighet for ekstremitetssparende kirurgi hos 72-96\% (16,17.). $64 \%$ av pasientene har bevart funksjon i behandlet ekstremitet (18). Lokal residivrate er $27 \%$, med median tid til residiv 14-31 måneder. Median femårsoverlevelse i denne pasientgruppen var 47 måneder, og median sykdomsspesifikk femårsoverlevelse $47-56 \%$ (18). 
Ved Radiumhospitalet har isolert ekstremitetsperfusjon vært benyttet hos 85 pasienter etter at metoden ble etablert i 2000. I perioden 2000-15 ble rundt fem pasienter behandlet med isolert ekstremitetsperfusjon per år, men de siste årene har antallet behandlede pasienter vært 1-2 per år. Det er vårt inntrykk at antall henvisninger til Radiumhospitalet for vurdering av isolert ekstremitetsperfusjon har avtatt de siste årene. Dette kan ha flere årsaker. Sannsynligvis er isolert ekstremitetsperfusjon en lite kjent behandlingsform. For melanomer kan endringen forklares ved at mer effektiv medikamentell behandling er blitt tilgjengelig. Til tross for dette får $64-79 \%$ av pasienter med metastatisk melanomsykdom progrediering $(\mathbf{1 9}, \underline{20})$. I nasjonalt handlingsprogram for melanomer er isolert ekstremitetsperfusjon anbefalt vurdert ved behandling av metastaser på ekstremiteter når

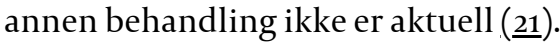

Isolert ekstremitetsperfusjon er i nasjonalt handlingsprogram for sarkomer anbefalt vurdert også som neoadjuvant behandling for lokalavanserte bløtvevssarkomer i ekstremiteter (22). Imidlertid har neoadjuvant systemisk kjemoterapi og preoperativ strålebehandling i økende grad erstattet isolert ekstremitetsperfusjon, dog uten vitenskapelig dokumentasjon på at slik behandling gir bedre behandlingsutfall $(\underline{2}, \underline{18}, \underline{2} 3)$. Vi vil derfor anta at flere pasienter med metastaser fra melanom til ekstremitet og lokalavanserte bløtvevssarkomer kan ha nytte av denne behandlingen.

\section{Oppsummering}

Isolert ekstremitetsperfusjon er et godt alternativ til behandling av behandlingsresistente metastaser fra melanom lokalisert til ekstremitet, med høy responsrate og akseptabel toksisitet. For bløtvevssarkomer er muligheten for ekstremitetssparende kirurgi med bevart funksjon oppnåelig hos $64 \%$ av pasientene. Færre enn en tredjedel av pasientene vil oppleve lokalt residiv, og over $40 \%$ er i live etter fem år. Antall pasienter som potensielt kunne ha nytte av isolert ekstremitetsperfusjon er sannsynligvis høyere enn det som gjenspeiles i dagens henvisningspraksis.

Artikkelen er fagfellevurdert.

\section{LITTERATUR}

1. Creech O, Krementz ET, Ryan RF et al. Chemotherapy of cancer: regional perfusion utilizing an extracorporeal circuit. Ann Surg 1958; 148: 616-32. [PubMed][CrossRef]

2. Tsagozis P, Brosjö O, Skorpil M. Preoperative radiotherapy of soft-tissue sarcomas: surgical and radiologic parameters associated with local control and survival. Clin Sarcoma Res 2018; 8: 19. [PubMed][CrossRef]

3. Nieweg OE, Kroon BB. Isolated limb perfusion with melphalan for melanoma. J Surg Oncol 2014; 109:332-7. [PubMed][CrossRef]

4. Lienard D, Ewalenko P, Delmotte JJ et al. High-dose recombinant tumor necrosis factor alpha in combination with interferon gamma and melphalan in isolation perfusion of the limbs for melanoma and sarcoma. J Clin Oncol 1992; 10:52-6o. [PubMed][CrossRef]

5. Eggermont AM, Schraffordt Koops H, Klausner JM et al. Isolated limb perfusion with tumor necrosis factor and melphalan for limb salvage in 186 patients with locally advanced soft tissue extremity sarcomas. The cumulative multicenter European experience. Ann Surg 1996; 224: 756-64. [PubMed][CrossRef]

6. Ahmed AE, Hsu TF, el-Azhary RA et al. Tissue distribution and macromolecular interactions of 14[Cring] melphalan in the rat. Cancer Chemother Pharmacol 1982; 8: 271-6. [PubMed][CrossRef]

7. Johansson J, Kiffin R, Andersson A et al. Isolated limb perfusion with melphalan triggers immune activation in melanoma patients. Front Oncol 2018; 8: 570. [PubMed][CrossRef]

8. de Wilt JH, ten Hagen TL, de Boeck G et al. Tumour necrosis factor alpha increases melphalan concentration in tumour tissue after isolated limb perfusion. Br J Cancer 2000; 82: 1000-3. [PubMed] [CrossRef] 
9. Moreno-Ramirez D, de la Cruz-Merino L, Ferrandiz L et al. Isolated limb perfusion for malignant melanoma: systematic review on effectiveness and safety. Oncologist 2010; 15: 416-27. [PubMed] [CrossRef]

10. Cornett WR, McCall LM, Petersen RP et al. Randomized multicenter trial of hyperthermic isolated limb perfusion with melphalan alone compared with melphalan plus tumor necrosis factor: American College of Surgeons Oncology Group Trial Zoo2o. J Clin Oncol 2006; 24: 4196-201. [PubMed] [CrossRef]

11. Madu MF, Deken MM, van der Hage JA et al. Isolated limb perfusion for melanoma is safe and effective in elderly patients. Ann Surg Oncol 2017; 24: 1997-2005. [PubMed][CrossRef]

12. Hildebrandt B, Wust $\mathrm{P}$, Ahlers $\mathrm{O}$ et al. The cellular and molecular basis of hyperthermia. Crit Rev Oncol Hematol 2002; 43: 33-56. [PubMed][CrossRef]

13. Wieberdink J, Benckhuysen C, Braat RP et al. Dosimetry in isolation perfusion of the limbs by assessment of perfused tissue volume and grading of toxic tissue reactions. Eur J Cancer Clin Oncol 1982; 18: 905-10. [PubMed][CrossRef]

14. Grunhagen DJ, de Wilt JH, Graveland WJ et al. Outcome and prognostic factor analysis of 217 consecutive isolated limb perfusions with tumor necrosis factor-alpha and melphalan for limbthreatening soft tissue sarcoma. Cancer 2006; 106: 1776-84. [PubMed][CrossRef]

15. Möller MG, Lewis JM, Dessureault $S$ et al. Toxicities associated with hyperthermic isolated limb perfusion and isolated limb infusion in the treatment of melanoma and sarcoma. Int J Hyperthermia 2008; 24: 275-89. [PubMed][CrossRef]

16. Martin-Tellez KS, van Houdt WJ, van Coevorden F et al. Isolated limb perfusion for soft tissue sarcoma: Current practices and future directions. A survey of experts and a review of literature. Cancer Treat Rev 2020; 88: 102058. [PubMed][CrossRef]

17. Olofsson R, Bergh P, Berlin O et al. Long-term outcome of isolated limb perfusion in advanced soft tissue sarcoma of the extremity. Ann Surg Oncol 2012; 19: 1800-7. [PubMed][CrossRef]

18. Deroose JP, Eggermont AM, van Geel AN et al. Long-term results of tumor necrosis factor alphaand melphalan-based isolated limb perfusion in locally advanced extremity soft tissue sarcomas. J Clin Oncol 2011; 29: 4036-44. [PubMed][CrossRef]

19. Larkin J, Chiarion-Sileni V, Gonzalez R et al. Five-year survival with combined nivolumab and ipilimumab in advanced melanoma. N Engl J Med 2019;381: 1535-46. [PubMed][CrossRef]

20. Robert C, Grob JJ, Stroyakovskiy D et al. Five-year outcomes with dabrafenib plus trametinib in metastatic melanoma. N Engl J Med 2019;381: 626-36. [PubMed][CrossRef]

21. Helsedirektoratet. Nasjonalt handlingsprogram med retningslinjer for diagnostikk, behandling og oppfølging av maligne melanomer, 22.5.2020. https://www.helsebiblioteket.no/retningslinjer/maligne-melanomer Lest 21.6.2021.

22. Helsedirektoratet. Nasjonalt handlingsprogram med retningslinjer for diagnostikk, behandling og oppfølging av sarkom, 10.4.2018. https://www.helsebiblioteket.no/retningslinjer/sarkomer/ Lest 21.6.2021.

23. Noorda EM, Vrouenraets BC, Nieweg OE et al. Isolated limb perfusion: what is the evidence for its use? Ann Surg Oncol 2004; 11: 837-45. [PubMed][CrossRef]

Publisert: 19. august 2021. Tidsskr Nor Legeforen. DOI: 10.4045/tidsskr.21.0194

Mottatt 9.3.2021, første revisjon innsendt 17.6.2021, godkjent 21.6.2021.

Publisert under åpen tilgang CC BY-ND. Lastet ned fra tidsskriftet.no 26. april 2023. 